\title{
Biogeography in the air: fungal diversity over land and oceans
}

\author{
J. Fröhlich-Nowoisky ${ }^{1,2}$, S. M. Burrows ${ }^{3}$, Z. Xie ${ }^{1,4}$, G. Engling ${ }^{5,6}$, P. A. Solomon ${ }^{7}$, M. P. Fraser ${ }^{8}$, \\ O. L. Mayol-Bracero ${ }^{9}$, P. Artaxo ${ }^{10}$, D. Begerow ${ }^{11}$, R. Conrad ${ }^{12}$, M. O. Andreae ${ }^{1}$, V. R. Després ${ }^{2,13}$, and U. Pöschl ${ }^{1,2}$ \\ ${ }^{1}$ Biogeochemistry Department, Max Planck Institute for Chemistry, P.O. Box 3060, 55020 Mainz, Germany \\ ${ }^{2}$ Earth System Science Center, Institute of Geosciences, Johannes Gutenberg University, Joh.-Joachim-Becher-Weg 21, \\ 55128 Mainz, Germany \\ ${ }^{3}$ Atmospheric Chemistry Department, Max Planck Institute for Chemistry, P.O. Box 3060, 55020 Mainz, Germany \\ ${ }^{4}$ Institute of Polar Environment, University of Science and Technology of China, Hefei, Anhui, 230026, China \\ ${ }^{5}$ Department of Biomedical Engineering and Environmental Sciences, National Tsing Hua University, Hsinchu 300, Taiwan \\ ${ }^{6}$ Research Center for Environmental Changes, Academia Sinica, Taipei 115, Taiwan \\ ${ }^{7}$ Office of Research and Development, National Exposure Laboratory, US EPA - Las Vegas, 944 E. Harmon Ave, \\ Rm. 235 Las Vegas, Nevada 89119, USA \\ ${ }^{8}$ Global Institute of Sustainability, Arizona State University, P.O. Box 875402, Tempe, AZ 85287-5402, USA \\ ${ }^{9}$ Institute for Tropical Ecosystem Studies, University of Puerto Rico, P.O. Box 70377, San Juan, PR 00936-8377, USA \\ ${ }^{10}$ Instituto de Fisica, Universidade de Sao Paulo, Sao Paulo, 05508-900 SP, Brazil \\ ${ }^{11}$ Department of Evolution and Biodiversity of Plants, Geobotany Section, Ruhr University Bochum, Universitätsstraße 150, \\ 44780 Bochum, Germany \\ ${ }^{12}$ Max Plank Institute for Terrestrial Microbiology, Karl-von-Frisch-Straße, Marburg 35043, Germany \\ ${ }^{13}$ Institute of General Botany, Johannes Gutenberg University, Johannes-von-Müller-Weg 6, 55128 Mainz, Germany \\ Correspondence to: J. Fröhlich-Nowoisky (j.frohlich@mpic.de)
}

Received: 20 June 2011 - Published in Biogeosciences Discuss.: 18 July 2011

Revised: 14 November 2011 - Accepted: 12 March 2012 - Published: 27 March 2012

\begin{abstract}
Biogenic aerosols are relevant for the Earth system, climate, and public health on local, regional, and global scales. Up to now, however, little is known about the diversity and biogeography of airborne microorganisms. We present the first DNA-based analysis of airborne fungi on global scales, showing pronounced geographic patterns and boundaries. In particular we find that the ratio of species richness between Basidiomycota and Ascomycota is much higher in continental air than in marine air. This may be an important difference between the "blue ocean" and "green ocean" regimes in the formation of clouds and precipitation, for which fungal spores can act as nuclei. Our findings also suggest that air flow patterns and the global atmospheric circulation are important for the understanding of global changes in biodiversity.
\end{abstract}

\section{Introduction}

The biogeographic distribution of microorganisms is a subject of ongoing discussion in microbial ecology (BassBecking, 1934; Finlay, 2002; Papke et al., 2003; Whitaker et al., 2003; Green et al., 2004; Whitfield, 2005; Martiny et al., 2006; Vos, 2008; Womack et al., 2010). One of the major issues debated is, whether only the environment drives biogeography as Baas-Becking postulates (Bass-Becking, 1934) or if other factors, e.g. historical events like dispersal limitations also can cause biogeographic distribution patterns. Recent studies have reported evidence for regional distribution patterns of microorganisms in soil and water (Papke at al., 2003; Whitaker et al., 2003; Green et al., 2004; Martiny et al., 2006; Whitfield, 2005; Vos, 2008), but patterns of global microbial distribution remain largely unknown. The majority of biogeographic studies have focused on terrestrial and marine environments (Womack et al., 2010), but little is known about biogeography in air, although air is the primary 
medium for the dispersal of microorganisms, connecting all ecosystems at the Earth's surface.

Fungal spores are ubiquitous in the Earth's atmosphere, where they can act as cloud condensation and ice nuclei and may thus influence the hydrological cycle and climate (Hamilton, 1998; Christner et al., 2008; Rosenfeld et al., 2008; Bowers et al., 2009; Henderson-Begg et al., 2009; Pratt et al., 2009; Prenni et al., 2009; Després et al., 2012). Moreover, certain fungi are major pathogens and allergens (Brown and Hovmøller, 2002; Madelin, 1994). Many fungi actively eject their spores with aqueous jets or droplets into the atmosphere, and the estimated global emissions are among the largest sources of organic aerosol $(\sim 30$ $50 \mathrm{Tg} \mathrm{a}^{-1}$; Elbert et al., 2007; Heald and Spracklen, 2009).

Earlier investigations of fungi in the environment, primarily based on cultivation techniques, found more species of Ascomycota (AMC) than of Basidiomycota (BMC). AMC are mostly single-celled (yeasts), filamentous (hyphal) or lichen-forming fungi, whereas the BMC comprise rusts, smuts, and most mushroom forming fungi that produce a diverse array of fruiting bodies.

Recent studies using DNA analysis, suggest that the species richness of BMC may actually be higher than that of AMC (Hunt et al., 2004; Fröhlich-Nowoisky et al., 2009). The question remains, however, whether the species richness of fungi in the atmosphere is generally higher for BMC than for AMC or if there are biogeographic regions in the air as suggested by Womack et al. (2010). Here we investigate the spread and diversity of airborne AMC, BMC, and various subgroups with optimized methods of extraction, amplification, and sequence analysis of DNA from the internal transcribed spacer (ITS) region (Fröhlich-Nowoisky et al., 2009).

\section{Material and methods}

\subsection{Aerosol sampling}

Samples were collected at several locations around the world, as detailed below and summarized in Table S1 and Fig. 1.

\subsubsection{Austria}

Four PM10 samples on quartz fiber filters (Tissuquartz 2500QAT-UP, $150 \mathrm{~mm}$ diameter, Pall, USA) were provided by the Institute for Chemical Technologies and Analytics, Vienna University of Technology, Vienna, Austria. The quartz fiber filters were not decontaminated before use. The samples were taken using a high-volume filter sampler (Digitel DA80H, Switzerland, sample air flow $\sim 500 \mathrm{~L} \mathrm{~min}^{-1}$, sampling time $24 \mathrm{~h}, 4 \mathrm{~m}$ above ground) in parallel at two sampling sites in Vienna in July 2005 (Table S2; Bauer at al., 2008). The samples were shipped at reduced temperatures and stored in a freezer at $-80^{\circ} \mathrm{C}$ until DNA extraction. The suburban site $\left(48^{\circ} 14^{\prime} 09^{\prime \prime} \mathrm{N}, 16^{\circ} 18^{\prime} 10^{\prime \prime} \mathrm{E}\right)$ was situated in a park-like residential area in the northwest of the city, next to a park bordered by woodland. The urban site $\left(48^{\circ} 11^{\prime} 05^{\prime \prime} \mathrm{N}\right.$, $16^{\circ} 24^{\prime} 28^{\prime \prime} \mathrm{E}$ ) was situated in a mixed residential/industrial area on a grassy strip with trees and bushes between a sidewalk and a street. A major urban freeway passed within around $200 \mathrm{~m}$.

\subsubsection{Arizona}

Ten samples were collected with a high-volume filter sampler (Tisch Environmental, Inc., USA; Sardar et al., 2006; inlet at $2 \mathrm{~m}$ above ground level, sample air flow $1000 \mathrm{~L} \mathrm{~min}^{-1}$; sampling time $7 \mathrm{~min}-24 \mathrm{~h}, 10$ samples, 2 blank samples) in February and March 2009 in Pinal County (32 $53^{\prime} 27.76^{\prime \prime} \mathrm{N}$, $111^{\circ} 34^{\prime} 14.49^{\prime \prime} \mathrm{W}$, Arizona; Table S3). The sampler had a PM10 inlet (Sierra Anderson, USA) after which sampled particles were split into fine $(<4.5 \mu \mathrm{m})$ and coarse $(4.5 \mu \mathrm{m}-10 \mu \mathrm{m})$ fractions. Fine particles were collected on a $20.3 \mathrm{~cm} \times 25.4 \mathrm{~cm}$ on quartz fiber filter at a flow rate of $900 \mathrm{~L} \mathrm{~min}^{-1}$ whereas coarse particles were collected on a $10.2 \mathrm{~cm}$ diameter quartz fiber filter at a flow rate of $100 \mathrm{~L} \mathrm{~min}^{-1}$. Prior to use, all filters were decontaminated by baking at $550^{\circ} \mathrm{C}$ for $8 \mathrm{~h}$ in clean aluminum foil. Annealed glass jars were used for storage and shipping before and after sampling. The samples were shipped at reduced temperatures and stored at $-80^{\circ} \mathrm{C}$ until DNA extraction.

The sampling site was situated in a desert area with significant agriculture approximately $17 \mathrm{~km}$ east of the town of Casa Grande, AZ. The site was immediately surrounded (within the first $\sim 0.5 \mathrm{~km}$ ) by desert shrub and bare soil. Outside of this area the site was surrounded primarily by crop farming and some dairy farming. Two lane roads with modest traffic were set at $0.5 \mathrm{~km}$ distances in $\mathrm{N}-\mathrm{S}, \mathrm{E}-\mathrm{W}$ directions in this region. The area experiences about $25 \mathrm{~cm}$ of precipitation annually on average, most occurring in JulyAugust and December-February with wintertime temperatures ranging from just above freezing to $20^{\circ} \mathrm{C}$; summertime from $25-45^{\circ} \mathrm{C}$.

\subsubsection{Brazil}

Coarse and fine particle samples (Table S4) were collected in Rondônia, Brazil $\left(10^{\circ} 45^{\prime} 44^{\prime \prime} \mathrm{S}, 62^{\circ} 21^{\prime} 27^{\prime \prime} \mathrm{W}\right)$ during the Large-Scale Biosphere-Atmosphere Experiment in Amazonia-Smoke, Aerosols, Clouds, Rainfall, and Climate (LBA-SMOCC) field campaign from September to November 2002, which corresponds to the most active biomass burning period in this region. The samples were collected on Pallflex quartz filters, preheated at $600{ }^{\circ} \mathrm{C}$ for at least $10 \mathrm{~h}$. Coarse and fine aerosol samples were taken with a dichotomous high-volume filter sampler (Solomon et al., 1983; sample air flow $272 \mathrm{~L} \mathrm{~min}^{-1}$, nominal cut-off diameter of $\sim 3 \mu \mathrm{m}$, sampling time $10-50 \mathrm{~h}$ ) mounted on a $10 \mathrm{~m}$ high tower as described in Hoffer et al. (2006). The samples were stored in a freezer at $-20^{\circ} \mathrm{C}$ until DNA extraction. In this study only 


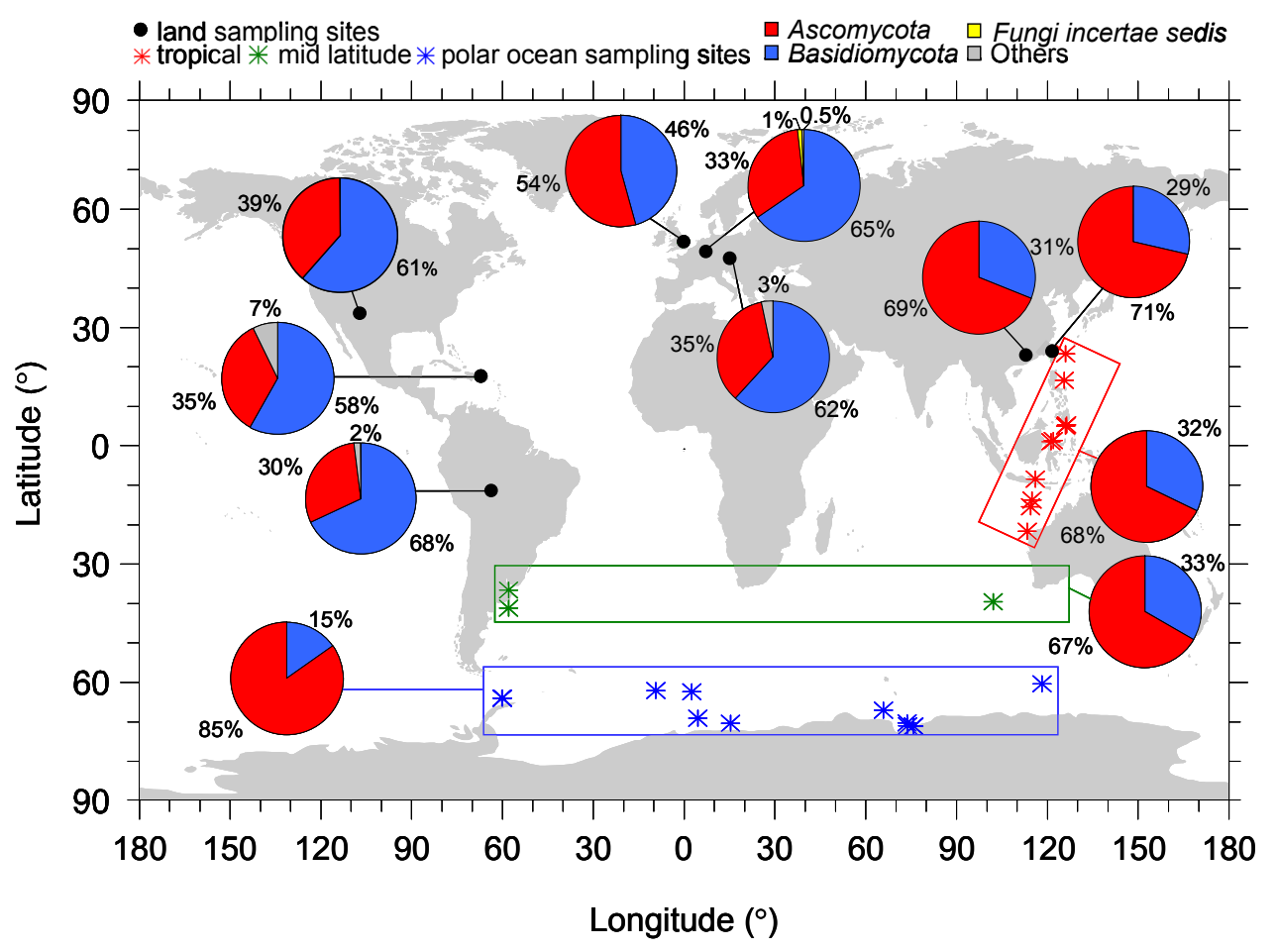

Fig. 1. Geographical location and relative proportions of different phyla in continental, coastal, and marine (ocean) sampling locations.

the coarse-particle aerosol samples (13 samples and 1 blank sample) were analyzed.

The sampling site was located in the south-western part of the Amazon Basin. The vegetation was dominated by grass and very few isolated palms and bushes, and the site was used as a cattle ranch. Low hills (300 to $440 \mathrm{~m}$ ) are located at a distance of 3 to $4 \mathrm{~km}$. The pasture was a rural, non-pristine site, with a highway at a distance of $10 \mathrm{~km}$ to the northeast (Trebs et al., 2004).

\subsubsection{China}

Samples of total suspended particles (TSP) were collected on quartz fiber filters with a high-volume filter sampler (Anderson Instruments, Smyrna, GA; $1.5 \mathrm{~m}$ above the ground, sample air flow $1000 \mathrm{Lmin}^{-1}$; sampling time $2-26 \mathrm{~h}, 14$ samples, 3 blank samples) during the Program of Regional Integrated Experiments of Pearl River Delta Region (PRIDE-PRD) Campaign in July 2006 in Backgarden $\left(23^{\circ} 54^{\prime} 80.56^{\prime \prime} \mathrm{N}, 113^{\circ} 06^{\prime} 63.89^{\prime \prime} \mathrm{E}\right.$, South China; Table S5). Prior to use, all filters were decontaminated by baking at $500{ }^{\circ} \mathrm{C}$ for at least $12 \mathrm{~h}$. The samples were stored in a freezer at $-80^{\circ} \mathrm{C}$ until DNA extraction.

Backgarden is a small village in a rural farming environment $\sim 60 \mathrm{~km}$ northwest of the megacity Guangzhou on the outskirts of the densely populated centre of the PRD. The sampling site was situated on the edge of the highly populated PRD region, though the area itself was mostly a farming area. Due to the prevailing monsoon circulation at this time of year, the air masses came mainly from the south/southeast, making this site a rural receptor site for the regional pollution resulting from the outflow of the city cluster around Guangzhou (Rose et al., 2008; Garland et al., 2009).

\subsubsection{Germany}

Aerosol samples (42 pairs of fine and coarse particle samples) were collected over one year in Mainz, Germany (130 m a.s.l., March 2006-April 2007). A high-volume dichotomous sampler (self-built based on Solomon et al., 1983) was used to separate and collect coarse and fine aerosol particles on a pair of glass fiber filters (Pall Corporation, Type $\mathrm{A} / \mathrm{A}, 102 \mathrm{~mm}$ diameter). The sampler was operated with a rotary vane pump (Becker VT 4.25) at a total flow rate of $\sim 300 \mathrm{~L} \mathrm{~min}^{-1}$, corresponding to a nominal cut-off diameter of $\sim 3 \mu \mathrm{m}$. Coarse particles with aerodynamic diameters larger than the virtual impactor cut-off were collected on a glass fiber filter $\left(\sim 30 \mathrm{~L} \mathrm{~min}^{-1}\right)$, and fine particles with aerodynamic diameters smaller than the cut-off were collected on a second glass fiber filter $\left(\sim 270 \mathrm{~L} \mathrm{~min}^{-1}\right)$. The sampling period was generally $\sim 7$ days, corresponding to a sampled air volume of $\sim 3000 \mathrm{~m}^{3}$. A few samples were collected over shorter periods (1-5 days, $\sim 400-2000 \mathrm{~m}^{3}$ ). The sampling station was positioned on a mast at the top of the Max Planck Institute for Chemistry (MPIC, about $5 \mathrm{~m}$ above the flat roof of the 3-story building) on the campus of the University of 
Mainz ( $\left.49^{\circ} 59^{\prime} 31.36^{\prime \prime} \mathrm{N} 8^{\circ} 14^{\prime} 15.22^{\prime \prime} \mathrm{E}\right)$. The air masses sampled at MPIC represent a mix of urban and rural continental boundary layer air in central Europe. Prior to use, all glass fiber filters were decontaminated by baking at $500^{\circ} \mathrm{C}$ over night. Loaded filters were packed in aluminum foil (also prebaked at $500{ }^{\circ} \mathrm{C}$ ), and stored in a freezer at $-80^{\circ} \mathrm{C}$ until DNA extraction. To detect possible contaminations from the sampler and sample handling, blank samples were taken at regular intervals ( $\sim 4$ weeks). Prebaked filters were mounted in the sampler like for regular sampling, but the pump was turned on either not at all ("mounting blanks") or for only $5 \mathrm{~s}$ ("start-up blank"). A comprehensive description of the investigated samples of this site is given in Fröhlich-Nowoisky et al. (2009).

\subsubsection{Puerto Rico}

Air samples on quartz fiber filters (stacked filter unit, $\mathrm{D}_{p}<$ $1.7 \mu \mathrm{m}$, Pallflex Tissuquartz 2500 QAT-UP) and Nuclepore filters $\left(\mathrm{D}_{p}>1.7 \mu \mathrm{m}\right.$, PC Membrane, Corning Costar, nominal pore size $8.0 \mu \mathrm{m}$ ) were collected on two stacked-filter units (protected against rain) mounted in parallel, during summer 2007 by the Institute for Tropical Ecosystem Studies (ITES), University of Puerto Rico, USA at three different locations in Puerto Rico (Table S6). The sampling stations were Cape San Juan in Fajardo (marine site $18^{\circ} 22^{\prime} 52.90^{\prime \prime} \mathrm{N}$, $65^{\circ} 37^{\prime} 5.52^{\prime \prime} \mathrm{W}, 60 \mathrm{~m}$ a.s.l., aerosol inlet at the top of a $10 \mathrm{~m}$ tower), the University of Puerto Rico-Río Piedras (urban site, $18^{\circ} 24^{\prime} 17.49^{\prime \prime} \mathrm{N}, 66^{\circ} 02^{\prime} 51.03^{\prime \prime} \mathrm{W}, 26 \mathrm{~m}$ a.s.l., inlet $2 \mathrm{~m}$ above the roof of the Facundo Bueso building) and the El Yunque National Forest (forest site, $18^{\circ} 19^{\prime} 13.01^{\prime \prime} \mathrm{N}$, $65^{\circ} 45^{\prime} 02.52^{\prime \prime} \mathrm{W}, 350 \mathrm{~m}$ a.s.l., aerosol inlet at the top of a $22 \mathrm{~m}$ tower). The sample air flow was $50 \mathrm{~L} \mathrm{~min}^{-1}$ and the sampling time $48-72 \mathrm{~h}$. Prior to use, all quartz fiber filters were decontaminated by baking at $450^{\circ} \mathrm{C}$ for $24 \mathrm{~h}$, while the Nuclepore filter were not decontaminated. The samples were shipped at reduced temperatures and stored in a freezer at $-80^{\circ} \mathrm{C}$ until DNA extraction. In total 11 samples and 5 blank samples (baked and unbaked filter) were analyzed.

\subsubsection{Taiwan}

PM2.5 and TSP samples on quartz fiber filters (Tissuquartz 2500 QAT-UP, $20 \mathrm{~cm} \times 25 \mathrm{~cm}$, Pall Corporation, USA) were collected by the Research Center for Environmental Changes, Taiwan (Table S7). Prior to use, all quartz fiber filters were decontaminated by baking at $500{ }^{\circ} \mathrm{C}$ for at least $8 \mathrm{~h}$. The samples were collected between October 2006 and June 2008 using high-volume filter samplers (Ecotech HVS3000 PM2.5 and Thermo Andersen TSP Hi-Vol, sample air flow $1130 \mathrm{~L} \mathrm{~min}^{-1}$; sampling time $12-24 \mathrm{~h}$ ) at several locations in Taiwan. PM2.5 samples were collected in Nangang, Taipei (suburban site, $25^{\circ} 02^{\prime} 31.2^{\prime \prime} \mathrm{N}, 121^{\circ} 37^{\prime} 0.3 \mathrm{E}$, $21.9 \mathrm{~m}$ a.s.1., northern Taiwan). The sampling station was positioned on the flat roof of the 4-story building of the Institute of Earth Sciences (IES) at the campus of Academia Sinica. TSP samples were taken in Yunlin County $\left(23^{\circ} 42^{\prime} 91^{\prime \prime} \mathrm{N}\right.$, $120^{\circ} 34^{\prime} 17.9^{\prime \prime} \mathrm{E}, 175 \mathrm{~m}$ a.s.l., south-central Taiwan). The sampler was placed on top of a 6-story building on the campus of the National Yunlin University of Science at the edge of Douliou City, a medium-size city of a few hundred thousand inhabitants. Furthermore, PM2.5 samples were collected at the Taiwan Forest Research Institute, Liougui, Kaohsiung County $\left(22^{\circ} 55^{\prime} \mathrm{N}\right.$; $120^{\circ} 41^{\prime} \mathrm{E}, 750 \mathrm{~m}$ a.s.l., southern Taiwan). This remote site is at an intermediate altitude in the southern part of the central Taiwan mountain range. The air sampled at all three locations represents mainly marine air masses. The samples were shipped at reduced temperatures and stored in a freezer at $-80^{\circ} \mathrm{C}$ until DNA extraction. In total 13 samples and 3 blank samples were analyzed.

\subsubsection{United Kingdom}

Samples on glass fiber filters (Graseby Andersen Hi-Vol six-stage impactor, sample air flow $1120 \mathrm{~L} \mathrm{~min}^{-1}$, sampling time $21-35 \mathrm{~h}$ ) were provided by the School of Earth, Atmospheric, and Environmental Sciences, University of Manchester, United Kingdom (UK). The samples were collected as part of the Tropospheric ORganic CHemistry (TORCH) field campaigns during summer 2003 and spring 2004 (Table S8). Prior to use, the glass fiber filters were decontaminated by baking and the loaded filters were shipped at reduced temperatures and stored in a freezer at $-20^{\circ} \mathrm{C}$ until DNA extraction. The TORCH1 sampling site was located at Writtle Agricultural College, near Chelmsford, Essex, UK, $\left(51^{\circ} 73^{\prime} 99^{\prime \prime} \mathrm{N}\right.$, $\left.0^{\circ} 41^{\prime} 46^{\prime \prime} \mathrm{E}\right), \sim 50 \mathrm{~km}$ northeast of London. The site was on a $\sim 1.5$ ha grass field situated to the southeast of the main college buildings, and was not influenced by any significant local vehicular, domestic or industrial sources. The air masses were dominated by prevailing winds from the Atlantic, with air mainly arriving at the measurement site from a westerly or south-westerly direction (Ireland, Southern UK) thus giving the opportunity to sample air recently flowing out from the London area (Johnson et al., 2006; Cubison et al., 2006). Three samples were analyzed. TORCH2 took place at the Weybourne Atmospheric Observatory (WAO, $52^{\circ} 57^{\prime} 02^{\prime \prime} \mathrm{N}$, $1^{\circ} 07^{\prime} 19^{\prime \prime} \mathrm{E}$ ), which is located on the North Norfolk coastline near Weybourne, UK. Norfolk is a sparsely populated rural region without large population centers or industrial areas. As detailed by Gysel et al. (2007) the air masses encountered at this station represent aged polluted outflow from London, the West Midlands or the European continent, or relatively clean air masses transported across the North Sea region by northerly wind. The analyzed samples ( 8 samples, 4 blanks) were mainly influenced by marine air masses from the North Sea. 


\subsubsection{Ocean (Ship sampling)}

TSP samples of tropical, mid-latitude, and sub-polar marine boundary layer air were collected during the 24th China Antarctic Research Expedition (October 2007 to April 2008, Antarctic summer) on glass fiber filters $(23 \mathrm{~cm} \times 18 \mathrm{~cm})$ using a high-volume filter sampler (sample air flow $1005 \mathrm{~L} \mathrm{~min}^{-1}$; sampling time 24-72 h; Table S9). The sampler was positioned on the platform of the Icebreaker Xuoelong (30 $\mathrm{m}$ a.s.l.). The cruise covered regions between China, Australia, Antarctica, and Argentina, including the East China Sea, South China Sea, South Pacific Ocean, East Indian Ocean, South Atlantic Ocean, and Southern Ocean (Fig. 1). Prior to use, all glass fiber filters were decontaminated by baking at $500{ }^{\circ} \mathrm{C}$ over night. To avoid ship emission contamination, a wind controller for the sampler was designed which stopped automatically when the velocity of the wind from the front of the ship was lower than $5 \mathrm{~m} \mathrm{~s}^{-1}$. The samples were stored at $-20^{\circ} \mathrm{C}$, shipped at reduced temperatures and stored in a freezer at $-80^{\circ} \mathrm{C}$ until DNA extraction. 17 samples and 2 blank samples were analyzed.

\subsubsection{Impact of different sampling methods and conditions}

As described above, the samples from different locations were collected with different types of samplers, cut-off diameters, and filter substrates. In addition, the sampled air volumes, sampling periods (year, season) and sample storage conditions were different (Tables S2-S9). These differences may have influenced the results obtained for different measurement locations as follows. Depending on sampler type and cut-off diameter, large spores or fungal tissue fragments are likely to be discriminated in certain types of samples (e.g. PM2.5 samples from Taiwan) and in others the inlet cut-off is wind speed dependent and possibly varying from $\sim 30$ to $100 \mu \mathrm{m}$. The sampling height can influence the impact of the surrounding area and vegetation. Larger particles as well as particles from fungi growing near the sampler may be preferentially collected by samplers at ground level, whereas sampling on elevated platforms, masts or towers is likely to be less influenced by local sources. Rare species are less likely to be found in case of short sampling times and low air volumes. The detection and apparent frequency of occurrence of different species can also be affected by the efficiency of DNA extraction from different kinds of filter material. Further investigations will be required to quantify such effects. Nevertheless, this study confirms that a wide range of filter materials can be used for DNA analysis of air samples (Després et al., 2007). Different climates might also influence recovery of DNA from air samples, because DNA starts to degrade as soon as an organism dies. Spores resist environmental stress and atmospheric transport and are thus unlikely to degrade during sampling (Griffin, 2004; Griffin and Kellogg, 2004). Fungal tissue fragments, however, may be more rapidly degraded in tropical climates because DNA is best preserved under dry and cool conditions (Pääbo at al., 2004; Després et al., 2007). Furthermore, different storage times and conditions might have led to different degrees of DNA degradation in the investigated sets of samples. Thus, different sampling and storage conditions should be kept in mind when comparing the different sets of filter samples investigated in this study. The comparability of absolute values of species richness determined for different sampling locations and regions is also limited by the different numbers of investigated samples. Nevertheless, the experimental results do not indicate any bias of the applied methods with regard to the relative proportions between AMC and BMC. The consistency of major trends and similarities observed over all types of samples suggests that the main findings and conclusions of this study (gross differences AMC/BMC in continental and marine air, major classes of $\mathrm{AMC}$ and $\mathrm{BMC}$, etc.) are not significantly affected by the uncertainties outlined above.

\subsection{DNA extraction and amplification}

Filter sample aliquots $(30-150 \mathrm{mg})$ were extracted with a commercial soil extraction kit (LysingMatrixE, Fast DNA Spin Kit for Soil, MP Biomedicals) according to the supplier's instructions with the following modifications: $15 \mathrm{~min}$ centrifugation step after the lysis, additional $900 \mu \mathrm{l}$ buffer, and repeated beating and centrifugation. Both generated supernatants were combined for the further extraction process. Finally, the DNA was dissolved in $100 \mu$ l elution buffer. Decontaminated filter aliquots and LysingMatrixE reaction tubes without filter aliquots were included as extraction blanks.

With the DNA extract from each of the filters listed in Tables S2-9, at least 4 PCRs were performed to amplify fungal DNA for sequence analysis. The 50- $\mu$ reaction mixture always contained the template DNA $(0.5-5 \mu \mathrm{l}$ sample extract), $1 \times$ PCR buffer, $0.2 \mathrm{mM}$ each dNTP (Roth), $0.33 \mu \mathrm{M}$ of each primer (Sigma-Aldrich), and 2.5 units of JumpStart ${ }^{T M}$ REDTaq DNA polymerase (Sigma-Aldrich). A negative control was included in all PCR runs.

PCR reactions were performed with the primer pairs listed in Table S11, except for the samples collected in Mainz, Germany, where more primer pairs were used (FröhlichNowoisky et al., 2009). For the first PCR primer pairs A, $\mathrm{B}$, and $\mathrm{C}$ and for the second $\mathrm{PCR}$ of the products $\mathrm{A}$ and $\mathrm{B}$, the nested primer pairs D, E, and/or F were used. The thermal profile (DNA Engine, Bio-Rad Laboratories) was as follows: initial denaturing at $94^{\circ} \mathrm{C}$ for $3 \mathrm{~min} ; 35$ cycles with denaturing at $94^{\circ} \mathrm{C}$ for $30 \mathrm{~s}$, annealing at primer pair specific temperature for $30 \mathrm{~s}$ (Table S11), elongation at $72^{\circ} \mathrm{C}$ for $90 \mathrm{~s}$, and a final extension step at $72{ }^{\circ} \mathrm{C}$ for $5 \mathrm{~min}$.

Fungal DNA was detected in $4 \%$ of the extraction or PCR blank reactions, indicating that contaminations occurred rarely during analysis in the laboratory. DNA was 
not detected in all PCR runs of the same extraction blank. No DNA could be detected in the baked and unbaked filter blanks. The PCR products obtained from blank samples were cloned and sequenced, whereas PCR products of filter extracts obtained in these PCRs were completely excluded from the cloning reactions (see Supplementary text).

\subsection{Cloning and restriction fragment length polymorphism}

Amplification products for sequencing were cloned using the TOPO TA Cloning ${ }^{\circledR}$ Kit (Invitrogen) following the supplier's instructions. Colonies containing inserts were identified by blue-white selection and lysed in $20 \mu \mathrm{l}$ water for 10 min at $95^{\circ} \mathrm{C}$. The inserts of 12-24 colonies were amplified ("colony PCRs") using $3 \mu \mathrm{l}$ lysate in a $40-\mu l$ reaction. The PCR reaction mixture always contained: $1 \times$ PCR Buffer, $0.25 \mathrm{mM}$ each dNTP (Roth), $0.25 \mu \mathrm{M}$ of each primer (SigmaAldrich), 1.25 units Taq DNA Polymerase (NEB). PCR reactions were performed with the primer pair M13F-40 and M13R, and the thermal profile was as follows: initial denaturing at $94^{\circ} \mathrm{C}$ for $5 \mathrm{~min} ; 40$ cycles with $94^{\circ} \mathrm{C}$ for $30 \mathrm{~s}$, annealing at $55^{\circ} \mathrm{C}$ for $1 \mathrm{~min}$, elongation at $72^{\circ} \mathrm{C}$ for $1 \mathrm{~min}$, and a final extension step at $72{ }^{\circ} \mathrm{C}$ for $15 \mathrm{~min}$.

The colony PCR was followed by restriction fragment length polymorphism (RFLP) analysis to select as many as possible different clones for sequencing. $2 \mu \mathrm{l}$ of the PCRproducts were digested without further purification with 5 units of the enzyme TaqI (Fermentas). Restriction fragments were separated by gel electrophoresis in a $3 \%$ agarose gel stained with ethidium bromide and the images were documented with the Gel Doc XR system and analyzed with Quantity One software (Bio-Rad Laboratories). On the basis of the resulting restriction fragment patterns, representative colony PCR products with different numbers and sizes of fragments were selected for sequencing.

\subsection{DNA sequence analysis, taxonomic attribution, and statistical parameters}

DNA sequences were determined with ABI Prism 377, 3100, and 3730 sequencers (Applied Biosystems) using BigDyeterminator v3.1 chemistry at the DNA Core Facility of the Max Planck Institute for Plant Breeding Research, Cologne. For comparison with known sequences, databank queries using the Basic Local Alignment Search Tool (BLAST) were performed via the website of the National Center for Biotechnology Information (NCBI, http://www.ncbi.nlm.nih.gov/). Out of 3360 sequenced clones 247 sequencing reactions failed and nine sequences produced non-fungal results. Each of the 3113 remaining sequences was identified to the lowest taxonomic rank common to the top BLAST hits (up to $\sim 100$ data base sequences with highest similarity and total scores). Sequences (51), for which the ITS1 and ITS2 regions matched in different genera and thus were assumed to be chimeric results of PCR recombination. These sequences and were excluded from further analysis. Sequences (399), which were obtained from field, extraction or PCR blanks and identical sequences obtained from the air filter samples and filter blank samples were also excluded from further analysis.

For each aerosol filter sample, sequences that produced the same BLAST results were pairwise aligned using the program BioEdit (BioEdit 7.1.3; http://www.mbio.ncsu.edu/ bioedit/bioedit.html). The similarity between them was calculated using the PAM250 Matrix. Sequences with similarity scores $\geq 97 \%$ were clustered into an operational taxonomic unit (OTU).

To characterize and compare the diversity of fungal species (OTUs) in the investigated air masses, we have calculated the parameters defined in Table S12.

The sequences from the obtained OTUs of the present study have been deposited in the GenBank database under following accession numbers: FJ820489-FJ820856 (Germany), GQ851628-GQ851902 (China), GQ999130GQ999328 (Ocean), GQ999329-GQ999418 (Austria), GQ999419-GQ999567 (Taiwan), GU05384-GU053981 (Brazil), GU053982-GU054180 (Puerto Rico), GU054181GU054336 (UK), and JF289074-JF289166 (Arizona).

\subsection{Global atmospheric transport model simulation}

To simulate the effect of fungal spore size on the global geographic distribution of relative species abundance, we implemented a fungal spore emissions parameterization in the global model ECHAM/MESSy-Atmospheric Chemistry (EMAC; Jöckel et al., 2006). The model simulates atmospheric transport and size-dependent aerosol loss processes (removal by precipitation and dry deposition onto land and water).

All model simulations were conducted using EMAC version 1.9. The following MESSy submodels were utilized for simulation of aerosol emission and deposition processes: online emissions via ONLEM (Kerkweg et al., 2006a), wet deposition (impaction and nucleation scavenging) via SCAV (Tost et al., 2006) [including modifications to that submodel described elsewhere (Tost et al., 2010)], and sedimentation and dry deposition via SEDI and DRYDEP, respectively (Kerkweg et al., 2006b).

To calculate exemplary atmospheric residence times for emissions from different ecosystems, we applied homogeneous emissions analogous to Burrows et al. (2009), but with larger particles with sizes reflecting the size range of airborne fungal spores. Simulations were conducted in T63L 31 resolution for five simulated years (plus one year spin-up) with climatological sea surface temperatures and online calculation of atmospheric dynamics. Atmospheric residence times were calculated for different fungal spore sizes $(3 \mu \mathrm{m}, 5 \mu \mathrm{m}$, $7 \mu \mathrm{m}, 10 \mu \mathrm{m})$ and different source ecosystems. We assume an aerodynamic diameter of $3 \mu \mathrm{m}$ for AMC and 5-10 $\mu \mathrm{m}$ for 
BMC. Note that fungal spores can also be smaller or larger. These values used for the model simulations are characteristic for the most prominent airborne AMC and BMC.

\section{Results and discussion}

Air filter samples were collected at continental, coastal, and marine locations in tropical, mid-latitude, and sub-polar regions around the world (Fig. 1), as detailed in the methods section. For each location, the number of samples, fungal DNA sequences, and different operational taxonomic units which correspond to species (species richness, $\mathrm{S}$ ) as well as related statistical parameters are listed in the supplementary information (Table S1). Fungal DNA was found in all environments and in all except 8 of the 136 air samples investigated (Tabels S2-S9). The few samples in which no fungi could be detected were collected on a ship and in coastal regions (Tables S7-S9), consistent with earlier observations and model results indicating that fungi are not abundant in marine air and that the ocean is not a major source of fungal spores (Elbert et al., 2007; Heald and Spracklen, 2009).

The absolute values of observed species richness varied with the number and type of investigated air samples, ranging from $\mathrm{S}=18$ for the marine mid-latitude set (2 samples) to $S=364$ for the continental mid-latitude location of Mainz, Germany (42 samples). Estimates of the total species richness of fungi in the investigated air masses obtained with the Chao-1 estimator approach (S*) range from about 135 to 1100. The Shannon index $\left(\mathrm{H}^{\prime}\right)$, Shannon evenness $(\mathrm{E})$, and Simpson's index (D) values calculated from the frequency of occurrence of the different species, i.e. from the number of samples in which each species had been detected, are similar to the values commonly obtained for fungi in soil and on plants as well as for bacteria in soil (Maria et al., 2002; Hill et al., 2003; Richard et al., 2004; Satish et al., 2007; Fröhlich-Nowoisky et al., 2009) (Table S1). Due to well understood limitations of these parameters mentioned by Morris et al. (2002), we focus on the relative proportions of the species richness of different groups of fungi in the investigated samples and the resulting biogeographic patterns. The relative proportion of AMC and BMC discussed below are defined as the ratio of AMC or BMC to the total number of species detected in the samples.

Figure 2a shows the proportions of AMC, BMC, and other types of fungi averaged over all samples collected at continental, coastal, or marine locations, respectively. As illustrated, nearly all detected fungal species were BMC or AMC. This is consistent with the predominance of AMC and BMC in the biosphere, where they account for $98 \%$ of the known species in the biological kingdom of fungi (James et al., 2006). As expected, aquatic fungi of Chytridiomycota or endomycorrhiza of the Glomeromycota were not detected. The species richness of continental air was clearly dominated by
BMC $(64 \%)$, whereas AMC prevailed in marine air $(72 \%)$ and at coastal locations (57\%, Fig. 2a).

At all continental locations (Austria, Arizona, Brazil, Germany) the proportion of BMC species (61-68\%) was by a factor of $\sim 2$ higher than that of AMC species (30-39\%). In contrast, all marine sample sets (ship sampling sites) exhibited BMC species proportions (15-32\%) that were by factors around two to five times lower than the AMC species proportions $(67-85 \%)$.

The coastal locations (China, Taiwan, United Kingdom, Puerto Rico) showed a diverse picture. Those in China and Taiwan exhibited high proportions of AMC species (69$71 \%$ ), consistent with a prevalence of marine air masses during the sampling periods. In contrast, the coastal regions investigated in the United Kingdom and Puerto Rico exhibited lower proportions of AMC species $(54 \%$ and $35 \%$, respectively) and higher proportions of BMC species $(46 \%$ and $58 \%$ ). This can be explained by reduced prevalence of marine air masses. Several of the UK samples were influenced by air masses that were advected over land (BMC species proportion $84 \%$ ), and several of the Puerto Rico samples were collected in a rainforest environment (BMC species proportion $68 \%$; Figs. S1-3).

All available data indicate that the species richness of fungi is dominated by BMC in continental air masses and by AMC in marine air masses. To our knowledge, this is the first study to show large-scale patterns in the atmosphere, which indicates that there might be biogeographic regions in the air as suggested in the review by Womack et al. (2010).

The observed biogeographic patterns can be explained as follows: Emissions of fungal spores from the oceans are likely several orders of magnitude smaller than from land surfaces $\left(\sim 10 \mathrm{Mg} \mathrm{a}^{-1}\right.$ vs. $\sim 30-50 \mathrm{Tg} \mathrm{a}^{-1}$; Elbert et al., 2007; Heald and Spracklen, 2009). Thus, fungi in marine air likely originate from continental sources and long-range transport. Because the spores of many BMC $(\sim 5-10 \mu \mathrm{m})$ are typically larger than those of prominent airborne AMC ( 2-5 $\mu \mathrm{m}$ ) (Muilenberg, 1995; Lacey, 1996; Ingold, 2001; Stenlid, 2008; Fröhlich-Nowoisky et al., 2009), they are expected to have shorter atmospheric residence times and are less likely to undergo long-range transport as illustrated in Fig. S4 (Supplement). In analogy to the total concentration of biological aerosol particles (Matthias-Maser et al., 1997), the BMC/AMC ratio is thus expected to decrease with increasing distance from land. Additionally, the species richness of BMC is enhanced in the coarse fraction $(>3 \mu \mathrm{m})$, whereas the species richness of AMC is enhanced in the fine fraction $(<3 \mu \mathrm{m})$ of continental air particulate matter (Fröhlich-Nowoisky et al., 2009). If marine sources of fungal material are relevant, they are likely to enhance further the proportion of AMC, as several studies have reported that most of the 3000 fungal species and fungal biomass found in aquatic habitats consist of AMC (Nikolcheva and Bärlocher, 2004; Shearer et al., 2007). Thus, potential emissions of 

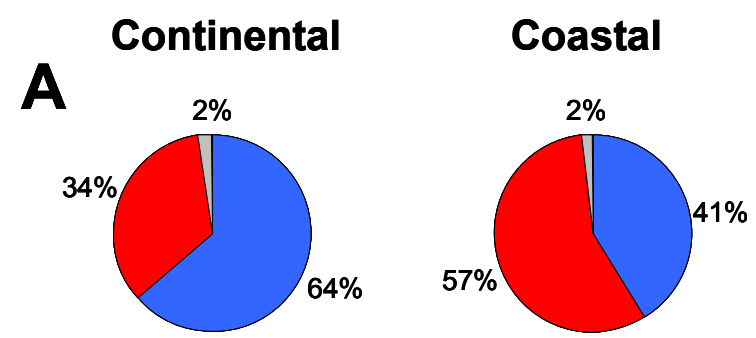

Marine

$\square$ Ascomycota $\square$ Basidiomycota $\square$ Others
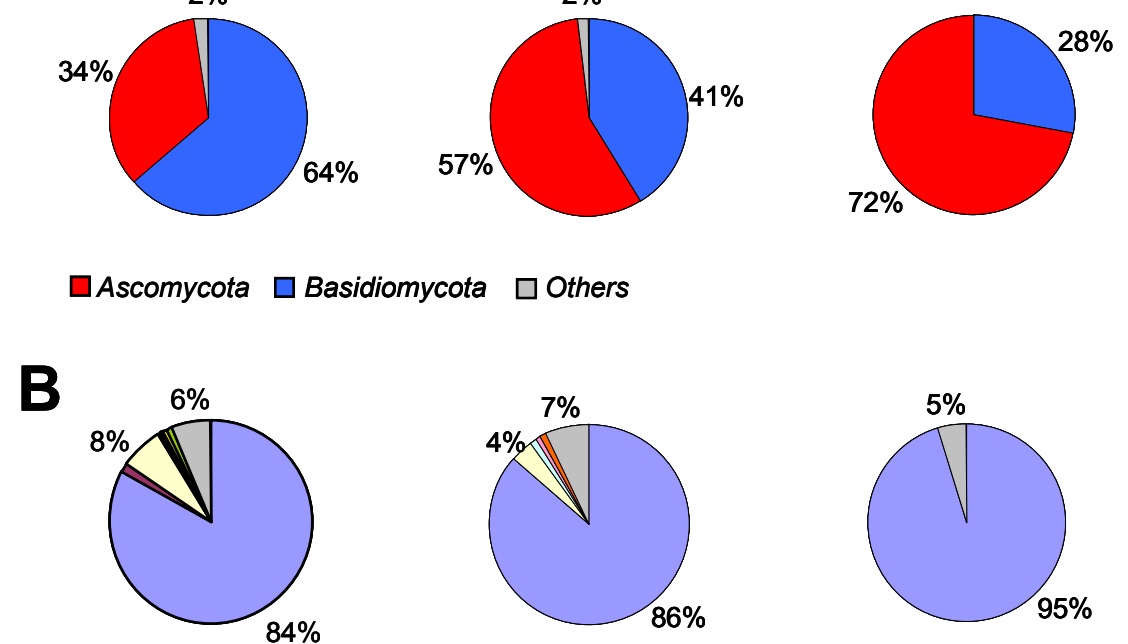
$\square$ Agaricomycetes
$\square$ Tremellomycetes
$\square$ Exobasidiomycetes
$\square$ Microbotryomycetes
$\square$ Pucciniomycetes
$\square$ Ustilaginomycetes $\square$ Wallemiomycetes
$\square$ Cystobasidiomycetes
$\square$ Agaricostilbomycetes $\square$ Others
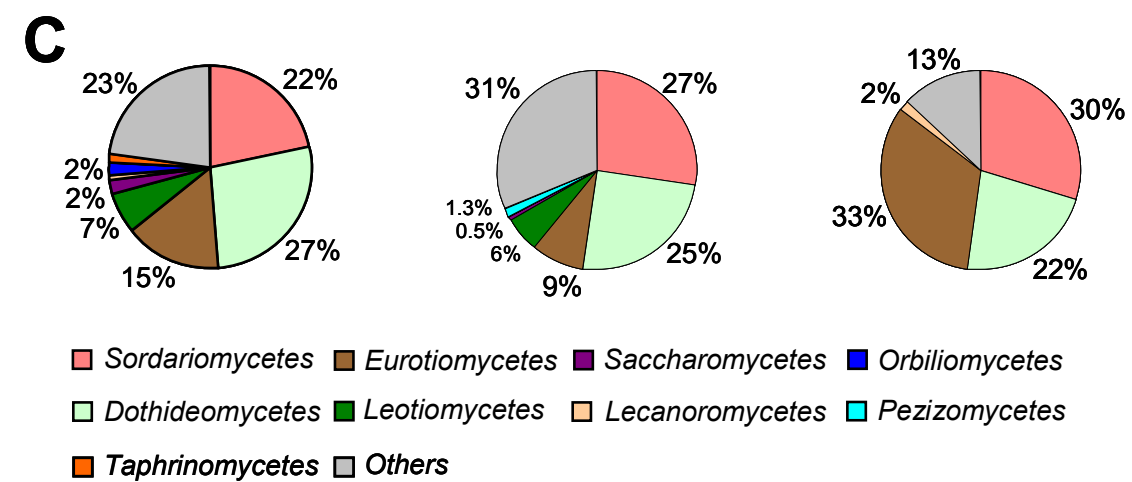

Orbiliomycetes

$\square$ Pezizomycetes

$\square$ Taphrinomycetes $\square$ Others

Fig. 2. Species richness of airborne fungi: mean relative proportions of different phyla (A), different classes of Basidiomycota (B), and different classes of Ascomycota (C) in continental (Austria, Arizona, Brazil, Germany), coastal (China, Taiwan, Puerto Rico, UK), and marine (Pacific, Indian, Atlantic, Southern Ocean) samples.

fungal material from the sea/ocean are likely to be smaller for BMC than for AMC.

Figure $2 \mathrm{~b}$ shows that most of the BMC species detected in continental, coastal, and marine air (84-95\%) belong to a single taxonomic class, the Agaricomycetes. This is also the most diverse class of BMC in the biosphere, where they account for $\sim 50 \%(\sim 16000)$ of the BMC species (Kirk et al., 2001; James et al., 2006). Agaricomycetes act as symbionts of temperate and boreal forests (ectomycorrhiza), as decomposers, or as parasites of plants or animals. Interestingly, the mostly plant parasitic classes of Pucciniomycetes (rusts) and Ustilaginomycetes (smuts), which are typical airborne plant pathogens, seem to play a minor role in terms of diversity and frequency of occurrence.
As shown in Fig. 2c, most AMC species (67-85\%) were distributed over four major taxonomic classes (Dothideomycetes, Sordariomycetes, Eurotiomycetes, and Leotiomycetes). They comprise plant and animal pathogens, symbionts, saprophytes, endophytes and epiphytes, and allergenic moulds (e.g. Cladosporium spp., Penicillium spp.).

Several ascomycotic moulds that are known to be abundant in the atmosphere were found everywhere (Cladosporium spp.) or in most sampling regions (Penicillium spp.; Table S10). These fungi are known to cause human allergies and respiratory problems (Madelin, 1994). In contrast, most of the BMC species (e.g. Suillus bovines, Coprinus cordisporus, and other species of Agaricomycetes) were found only in one sampling region. Note, however, that the probability 
of detecting rare species is limited by the limited number of air samples and sequenced DNA amplification products (clones) investigated for each region (Fröhlich-Nowoisky et al., 2009).

Members of fungal species that can act as ice nuclei (IN) (Jayaweera and Flanagan, 1982; Kieft and Ahmadjian, 1989; Pouleur et al., 1992; Iannone et al., 2011) were found in all regions: Cladosporium spp., Fusarium spp., Microdochium spp., Penicillium spp. (Table S10). While Cladosporium is the genus with the highest frequency of occurrence in continental air samples (98\%; Fröhlich-Nowoisky et al., 2009), Penicillium is the genus most frequently detected in marine samples $(60 \%)$. So far, all reported IN-active fungi belong to the AMC (Jayaweera and Flanagan, 1982; Kieft and Ahmadjian, 1989; Pouleur et al., 1992; Henderson-Begg et al., 2009; Iannone et al., 2011), but recent findings indicate that there are also IN-active fungal species from other phyla.

As described for pollen (Diehl et al., 2000), the IN activity of biological particles may increase with size. For mineral dust, it is well-known that rates of ice nucleation increase with particle surface area, i.e. larger dust particles are on average more efficient ice nuclei than smaller particles with similar chemical composition (Archuleta et al., 2005, Kanji et al., 2008, Welti et al., 2009). It seems plausible that a similar relationship would hold for fungal spores, with larger spores tending to be more effective IN than small spores. Ongoing investigations (Haga et al., 2012) suggest that there is indeed some correlation between spore size and median freezing temperature, and that spores of prominent BMC species may be more effective IN than spores of prominent AMC species. Particles that are more effective IN can be expected to be scavenged at higher rates in mixed-phase and ice clouds. Simulations of global atmospheric transport and removal processes suggest that the ability of particles to act as IN would affect their concentration in surface air primarily in polar regions (Bourgeios and Bey, 2011). Thus, if BMC are better IN than AMC, this could contribute to explaining the very low fraction of BMC species observed in the filter samples collected near the coast of Antarctica.

If fungal spores and other bioparticles are relevant as IN or giant $\mathrm{CCN}$ (cloud condensation nuclei), as suggested by several recent studies (Christner et al., 2008; Bowers et al., 2009, Pratt et al., 2009; Prenni et al., 2009), then the lower proportion of BMC in marine air may be an important difference between the "blue ocean" and "green ocean" regimes of cloud formation and precipitation (Andreae et al., 2004; Pöschl et al., 2010). Overall, the geographic distribution of bioaerosols may influence and provide insight into the diversity and spread of ecosystems, the hydrological cycle, climate and global change.

\section{Supplementary material related to this article is available online at: http://www.biogeosciences. net/9/1125/2012/bg-9-1125-2012-supplement.pdf.}

Acknowledgements. The corresponding authorship for this article is shared by J. Fröhlich-Nowoisky and V. R. Després (despres@uni-mainz.de). We thank H. Bauer, R. Burgess, A. L. Clements, R. M. Garland, A. Hoffer, K. Ibarra, D. Rose, H. Yang, and J. Z. Yu for providing filter samples, J. Cimbal, C. Fröhlich, I. Müller-Germann, and N. Knothe for technical assistance, A. K. Bertram, W. Elbert, S. Gunthe, M. Gysel, D. I. Haga, C. Morris, H. Paulsen and A. Wollny for discussions and support. Financial support was provided by the Max Planck Society (MPG), the LEC Geocycles in Mainz funded by the state Rheinland-Pfalz (Contribution No. 596), and the German Research Foundation (DE1161/2-1, PO1013/5-1, FOR 1525 INUIT). The United States Environmental Protection Agency through its Office of Research and Development partially collaborated in the research described here under assistance agreement number 83404901 to Arizona State University. It has been subjected to Agency review and approved for publication.

The service charges for this open access publication have been covered by the Max Planck Society.

Edited by: M. Marconcini

\section{References}

Andreae, M. O., Rosenfeld, D., Artaxo, P., Costa, A. A., Frank, G. P., Longo, K. M., and Silva-Dias, M. A. F.: Smoking rain clouds over the Amazon, Science, 303, 1337-1342, 2004.

Archuleta, C. M., DeMott, P. J., and Kreidenweis, S. M.: Ice nucleation by surrogates for atmospheric mineral dust and mineral dust/sulfate particles at cirrus temperatures, Atmos. Chem. Phys., 5, 2617-2634, doi:10.5194/acp-5-2617-2005, 2005.

Bass-Becking, L. G. M.: Geobiologie of Inleiding Tot de Melieukunde, Van Stockkum \& Zoon, The Hague, 1934.

Bauer, H., Schueller, E., Weinke, G., Berger, A., Hitzenberger, R., Marr, I. L., and Puxbaum, H.: Significant contributions of fungal spores to the organic carbon and to the aerosol mass balance of the urban atmospheric aerosol, Atmos. Environ., 42, 5542-5549, 2008.

Bourgeois, Q. and Bey, I.: Pollution transport efficiency toward the Arctic: Sensitivity to aerosol scavenging and source regions, J. Geophys. Res., 116, D08213, doi:10.1029/2010JD015096, 2011.

Bowers, R. M., Lauber, C. L., Wiedinmyer, C., Hamady, M., Hallar, A. G., Fall, R., Knight, R., and Fierer, N.: Characterization of Airborne Microbial Communities at a High-Elevation Site and Their Potential To Act as Atmospheric Ice Nuclei, Appl. Environ. Microbiol., 75, 5121-5130, doi:10.1128/aem.00447-09, 2009.

Brown, J. K. M. and Hovmøller, M. S.: Aerial dispersal of pathogens on the global and continental scales and its impact on plant disease, Science, 297, 537-541, 2002. 
Burrows, S. M., Butler, T., Jöckel, P., Tost, H., Kerkweg, A., Pöschl, U., and Lawrence, M. G.: Bacteria in the global atmosphere Part 2: Modeling of emissions and transport between different ecosystems, Atmos. Chem. Phys., 9, 9281-9297, doi:10.5194/acp-9-9281-2009, 2009.

Christner, B. C., Morris, C. E., Foreman, C. M., Cai, R. M., and Sands, D. C.: Ubiquity of biological ice nucleators in snowfall, Science, 319, 1214-1214, 2008.

Cubison, M. J., Alfarra, M. R., Allan, J., Bower, K. N., Coe, H., McFiggans, G. B., Whitehead, J. D., Williams, P. I., Zhang, Q., Jimenez, J. L., Hopkins, J., and Lee, J.: The characterisation of pollution aerosol in a changing photochemical environment, Atmos. Chem. Phys., 6, 5573-5588, doi:10.5194/acp-6-5573-2006, 2006.

Després, V. R., Nowoisky, J. F., Klose, M., Conrad, R., Andreae, M. O., and Pöschl, U.: Characterization of primary biogenic aerosol particles in urban, rural, and high-alpine air by DNA sequence and restriction fragment analysis of ribosomal RNA genes, Biogeosciences, 4, 1127-1141, doi:10.5194/bg-4-1127-2007, 2007.

Després, V. R., Huffman, J. A., Burrows, S. M., Hoose, C., Safatov, A. S., Buryak, G., Fröhlich-Nowoisky, J., Elbert, W., Andreae, M. O., Pöschl, U., and Jaenicke, R.: Primary biological aerosol particles in the atmosphere: a review, Tellus B, 64, doi:10.3402/tellusb.v64i0.15598, 2012.

Diehl, K., Matthias-Maser, S., Mitra, S. K., and Jaenicke, R.: Laboratory studies on the ice nucleating ability of biological aerosol particles in condensation freezing, immersion freezing, and contact freezing modes, J. Aerosol Sci., 31, 70-71, 2000.

Elbert, W., Taylor, P. E., Andreae, M. O., and Pöschl, U.: Contribution of fungi to primary biogenic aerosols in the atmosphere: wet and dry discharged spores, carbohydrates, and inorganic ions, Atmos. Chem. Phys., 7, 4569-4588, doi:10.5194/acp-7-4569-2007, 2007.

Finlay, B. J.: Global Dispersal of Free-Living Microbial Eukaryote Species, Science, 296, 1061-1063, doi:10.1126/science.1070710, 2002.

Fröhlich-Nowoisky, J., Pickersgill, D. A., Despres, V. R., and Pöschl, U.: High diversity of fungi in air particulate matter, Proc. Natl. Acad. Sci. USA, 106, 12814-12819, doi:10.1073/pnas.0811003106, 2009.

Garland, R. M., Yang, H., Schmid, O., Rose, D., Nowak, A., Achtert, P., Wiedensohler, A., Takegawa, N., Kita, K., Miyazaki, Y., Kondo, Y., Hu, M., Shao, M., Zeng, L. M., Zhang, Y. H., Andreae, M. O., and Pöschl, U.: Aerosol optical properties in a rural environment near the mega-city Guangzhou, China: implications for regional air pollution, radiative forcing and remote sensing, Atmos. Chem. Phys., 8, 5161-5186, doi:10.5194/acp-85161-2008, 2008.

Green, J. L., Holmes, A. J., Westoby, M., Oliver, I., Briscoe, D., Dangerfield, M., Gillings, M., and Beattie, A. J.: Spatial scaling of microbial eukaryote diversity, Nature, 432, 747-750, 2004.

Griffin, D. W.: Terrestrial microorganisms at an altitude of 20000 m in Earth's atmosphere, Aerobiologia, 20, 135-140, 2004.

Griffin, D. W. and Kellogg, C. A.: Dust storms and their impact on ocean and human health: dust in Earth's atmosphere, Ecohealth, 1, 284-295, 2004.

Gysel, M., Crosier, J., Topping, D. O., Whitehead, J. D., Bower, K. N., Cubison, M. J., Williams, P. I., Flynn, M. J., McFiggans, G. B., and Coe, H.: Closure study between chemical composition and hygroscopic growth of aerosol particles during TORCH2, Atmos. Chem. Phys., 7, 6131-6144, doi:10.5194/acp-7-61312007, 2007.

Haga, D. I., Iannone, R., Wheeler, M., Mason, R., and Bertram, A. K.: Fungal spores are efficient ice nuclei in the immersion mode, in preparation, 2012.

Hamilton, W. D. and Lenton, T. M.: Spora and Gaia: How microbes fly with their clouds, Ethology Ecology and Evolution, 10, 1-16, 1998.

Heald, C. L. and Spracklen, D. V.: Atmospheric budget of primary biological aerosol particles from fungal spores, Geophys. Res. Lett., 36, L09806, doi:10.1029/2009GL037493, 2009.

Henderson-Begg, S. K., Hill, T., Thyrhaug, R., Khan, M., and Moffett, B. F.: Terrestrial and airborne non-bacterial ice nuclei, Atmos. Sci. Lett., 10, 215-219, 2009.

Hill, T. C. J., Walsh, K. A., Harris, J. A., and Moffett, B. F.: Using ecological diversity measures with bacterial communities, FEMS Microbiol. Ecol., 43, 1-11, 2003.

Hoffer, A., Gelencsér, A., Guyon, P., Kiss, G., Schmid, O., Frank, G. P., Artaxo, P., and Andreae, M. O.: Optical properties of humic-like substances (HULIS) in biomass-burning aerosols, Atmos. Chem. Phys., 6, 3563-3570, doi:10.5194/acp-6-3563-2006, 2006.

Hunt, J., Boddy, L., Randerson, P. F., and Rogers, H. J.: An evaluation of $18 \mathrm{~S}$ rDNA approaches for the study of fungal diversity in grassland soils, Microb. Ecol., 47, 385-395, 2004.

Iannone, R., Chernoff, D. I., Pringle, A., Martin, S. T., and Bertram, A. K.: The ice nucleation ability of one of the most abundant types of fungal spores found in the atmosphere, Atmos. Chem. Phys., 11, 1191-1201, doi:10.5194/acp-11-1191-2011, 2011.

Ingold, C. T.: Range in size and form of basidiospores and ascospores, Mycologist, 15, 165-166, 2001.

James, T. Y., Kauff, F., Schoch, C. L., Matheny, P. B., Hofstetter, V., Cox, C. J., Celio, G., Gueidan, C., Fraker, E., Miadlikowska, J., Lumbsch, H. T., Rauhut, A., Reeb, V., Arnold, A. E., Amtoft, A., Stajich, J. E., Hosaka, K., Sung, G. H., Johnson, D., ORourke, B., Crockett, M., Binder, M., Curtis, J. M., Slot, J. C., Wang, Z., Wilson, A. W., Schussler, A., Longcore, J. E., ODonnell, K., Mozley-Standridge, S., Porter, D., Letcher, P. M., Powell, M. J., Taylor, J. W., White, M. M., Griffith, G. W., Davies, D. R., Humber, R. A., Morton, J. B., Sugiyama, J., Rossman, A. Y., Rogers, J. D., Pfister, D. H., Hewitt, D., Hansen, K., Hambleton, S., Shoemaker, R. A., Kohlmeyer, J., Volkmann-Kohlmeyer, B., Spotts, R. A., Serdani, M., Crous, P. W., Hughes, K. W., Matsuura, K., Langer, E., Langer, G., Untereiner, W. A., Lucking, R., Budel, B., Geiser, D. M., Aptroot, A., Diederich, P., Schmitt, I., Schultz, M., Yahr, R., Hibbett, D. S., Lutzoni, F., McLaughlin, D. J., Spatafora, J. W., and Vilgalys, R.: Reconstructing the early evolution of Fungi using a six-gene phylogeny, Nature, 443, 818-822, 2006.

Jayaweera, K. and Flanagan, P.: Investigations on biogenic ice nuclei in the Arctic atmosphere, Geophys. Res. Lett., 9, 94-97, 1982.

Johnson, D., Utembe, S. R., Jenkin, M. E., Derwent, R. G., Hayman, G. D., Alfarra, M. R., Coe, H., and McFiggans, G.: Simulating regional scale secondary organic aerosol formation during the TORCH 2003 campaign in the southern UK, Atmos. Chem. Phys., 6, 403-418, doi:10.5194/acp-6-403-2006, 2006.

Jöckel, P., Tost, H., Pozzer, A., Brühl, C., Buchholz, J., Ganzeveld, 
L., Hoor, P., Kerkweg, A., Lawrence, M. G., Sander, R., Steil, B., Stiller, G., Tanarhte, M., Taraborrelli, D., van Aardenne, J., and Lelieveld, J.: The atmospheric chemistry general circulation model ECHAM5/MESSy1: consistent simulation of ozone from the surface to the mesosphere, Atmos. Chem. Phys., 6, 50675104, doi:10.5194/acp-6-5067-2006, 2006.

Kanji, Z. A., Florea, O., Abbatt, J. P. D.: Ice formation via deposition nu-cleation on mineral dust and organics: Dependence of onset relative humidity on total particulate surface area, Environ. Res. Lett., 3, 025004, doi:10.1088/1748-9326/3/2/025004, 2008.

Kerkweg, A., Buchholz, J., Ganzeveld, L., Pozzer, A., Tost, H., and Jöckel, P.: Technical Note: An implementation of the dry removal processes DRY DEPosition and SEDImentation in the Modular Earth Submodel System (MESSy), Atmos. Chem. Phys., 6, 4617-4632, doi:10.5194/acp-6-4617-2006, 2006 a.

Kerkweg, A., Sander, R., Tost, H., and Jöckel, P.: Technical note: Implementation of prescribed (OFFLEM), calculated (ONLEM), and pseudo-emissions (TNUDGE) of chemical species in the Modular Earth Submodel System (MESSy), Atmos. Chem. Phys., 6, 3603-3609, doi:10.5194/acp-6-3603-2006, 2006.

Kieft, T. L. and Ahmadjian, V.: Biological Ice Nucleation Activity in Lichen Mycobionts and Photobionts, Lichenologist, 21, 355$362,1989$.

Kirk, P. M., Cannon, P. F., David, J. C., and Stalpers, J. A.: Ainsworth \& Bisby's Dictionary of the Fungi, 9th Edn. CABI Publishing, Wallingford, 2001.

Lacey, J.: Spore dispersal - its role in ecology and disease: the British contribution to fungal aerobiology, Mycol. Res., 100, 641-660, 1996.

Madelin, T. M.: Fungal aerosols: A review, J. Aerosol Sci., 25, 1405-1412, 1994.

Maria, G. L. and Sridhar, K. R.: Richness and diversity of filamentous fungi on woody litter of mangroves along the west coast of India, Curr. Sci., 83, 1573-1580, 2002.

Matthias-Maser, S., Krämer, M., Brinkmann, J., and Schneider, W.: A contribution of primary biological aerosol particles as insoluble component to the atmospheric aerosol over the south atlantic ocean, J. Aerosol Sci., 28, S3-S4, 1997.

Martiny, J. B. H., Bohannan, B. J. M., Brown, J. H., Colwell, R. K., Fuhrman, J. A., Green, J. L., Horner-Devine, M. C., Kane, M., Krumins, J. A., Kuske, C. R., Morin, P. J., Naeem, S., Ovreas, L., Reysenbach, A.-L., Smith, V. H., and Staley, J. T.: Microbial biogeography: putting microorganisms on the map, Nat. Rev. Micro., 4, 102-112, 2006.

Morris, C. E., Bardin, M., Berge, O., Frey-Klett, P., Fromin, N., Girardin H., Guinebretière, M.-H., Lebaron, P., Thiéry, J. M., and Troussellier, M.: Microbial biodiversity: approaches to experimental design and hypothesis testing in primary scientific literature from 1975 to 1999, Microbiol. Mol. Biol. Rev., 66, 592616, 2002

Muilenberg, M. L.: The outdoor aeroso, in: Bioaerosols, edited by: Burge, H. A., Boca Raton: CRC Press, 163-204, 1995.

Nikolcheva, L. G. and Bärlocher, F.: Taxon-specific fungal primers reveal unexpectedly high diversity during leaf decomposition in a stream, Mycol. Prog., 3, 41-49, 2004.

Pääbo, S., Poinar, H., Serre, D., Jaenicke-Després, V., Hebler, J., Rohland, N., Kuch, M., Krause, J., Vigilant, L., and Hofreiter, M.: Genetic analysis from ancient DNA, Ann. Rev. Genet., 38, 645-679, doi:10.1146/annurev.genet.37.110801.143214, 2004.
Papke, R., Ramsing, N. B., Bateson, M. M., and Ward, D. M.: Geographic isolation in hot spring cyanobacteria, Environ. Microbiol., 5, 650-659, 2003.

Pouleur, S., Richard, C., Martin, J. G., and Antoun, H.: Ice nucleation activity in Fusarium acuminatum and Fusarium avenaceum., Appl. Environ. Microbiol., 58, 2960-2964, 1992.

Pratt, K. A., DeMott, P. J., French, J. R., Wang, Z., Westphal, D. L., Heymsfield, A. J., Twohy, C. H., Prenni, A. J., and Prather, K. A.: In situ detection of biological particles in cloud ice-crystals, Nat. Geosci., 2, 398-401, 2009.

Prenni, A. J., Petters, M. D., Kreidenweis, S. M., Heald, C. L., Martin, S. T., Artaxo, P., Garland, R. M., Wollny, A. G., and Pöschl, U.: Relative roles of biogenic emissions and Saharan dust as ice nuclei in the Amazon basin, Nat. Geosci., 2, 402-405, 2009.

Pöschl, U., Martin, S. T., Sinha, B., Chen, Q., Gunthe, S. S., Huffman, J. A., Borrmann, S., Farmer, D. K., Garland, R. M., Helas, G., Jimenez, J. L., King, S. M., Manzi, A., Mikhailov, E., Pauliquevis, T., Petters, M. D., Prenni, A. J., Roldin, P., Rose, D., Schneider, J., Su, H., Zorn, S. R., Artaxo, P., and Andreae, M. O.: Rainforest aerosols as biogenic nuclei of clouds and precipitation in the Amazon, Science, 329, 1513-1516, 2010.

Richard, F., Moreau, P. A., Selosse, M. A., and Gardes, M.: Diversity and fruiting patterns of ectomycorrhizal and saprobic fungi in an old-growth Mediterranean forest dominated by Quercus ilex L., Can. J. Bot., 82, 1711-1729, 2004.

Rose, D., Nowak, A., Achtert, P., Wiedensohler, A., Hu, M., Shao, M., Zhang, Y., Andreae, M. O., and Pöschl, U.: Cloud condensation nuclei in polluted air and biomass burning smoke near the mega-city Guangzhou, China Part 1: Size-resolved measurements and implications for the modeling of aerosol particle hygroscopicity and CCN activity, Atmos. Chem. Phys. Discuss., 8, 17343-17392, doi:10.5194/acpd-8-17343-2008, 2008.

Rosenfeld, D., Lohmann, U., Raga, G. B., O’Dowd, C. D., Kulmala, M., Fuzzi, S., Reissell, A., and Andreae, M. O.: Flood or drought: How do aerosols affect precipitation? Science, 321, 1309-1313, 2008.

Sardar, S. B., Geller, M. D., Sioutas, C., and Solomon, P. A.: Development and evaluation of a high-volume dichotomous sampler for chemical speciation of coarse and fine particles, J. Aerosol Sci., 37, 1455-1466, 2006.

Satish, N., Sultana, S., and Nanjundiah, V.: Diversity of soil fungi in a tropical deciduous forest in Mudumalai, southern India, Curr. Sci., 93, 669-677, 2007.

Shearer, C. A., Descals, E., Kohlmeyer, B., Kohlmeyer, J., Marvanova, L., Padgett, D., Porter, D., Raja, H. A., Schmit, J. P., Thorton, H. A., and Voglymayr, D.: Fungal biodiversity in aquatic habitats, Biodivers. Conserv., 16, 49-67, 2007.

Solomon, P. A., Moyers, J. L., and Fletcher, R. A.: High-Volume Dichotomous Virtual Impactor for the Fractionation and Collection of Particles According to Aerodynamic Size, Aerosol Sci. Tech., 2, 455-464, 1983.

Stenlid, J.: Population biology of forest decomposer basidiomycetes, in: Ecology of saprotrophic basidiomycetes, edited by: Boddy, L., Frankland, J. C., van West, P., Academic Press, Amsterdam, The Netherlands, 105-122, 2008.

Tost, H., Jöckel, P., Kerkweg, A., Sander, R., and Lelieveld, J.: Technical note: A new comprehensive SCAVenging submodel for global atmospheric chemistry modelling, Atmos. Chem. Phys., 6, 565-574, doi:10.5194/acp-6-565-2006, 2006. 
Tost, H., Lawrence, M. G., Brühl, C., Jöckel, P., The GABRIEL Team, and The SCOUT-O3-DARWIN/ACTIVE Team: Uncertainties in atmospheric chemistry modelling due to convection parameterisations and subsequent scavenging, Atmos. Chem. Phys., 10, 1931-1951, doi:10.5194/acp-10-1931-2010, 2010.

Trebs, I., Meixner, F. X., Slanina, J., Otjes, R., Jongejan, P., and Andreae, M. O.: Real-time measurements of ammonia, acidic trace gases and water-soluble inorganic aerosol species at a rural site in the Amazon Basin, Atmos. Chem. Phys., 4, 967-987, doi:10.5194/acp-4-967-2004, 2004.

Vos, M. V. G.: Isolation by distance in spore-forming soil bacterium Myxococcus xantus, Curr. Biol., 18, 386-391, 2008.
Welti, A., Lüönd, F., Stetzer, O., and Lohmann, U.: Influence of particle size on the ice nucleating ability of mineral dusts, Atmos. Chem. Phys., 9, 6705-6715, doi:10.5194/acp-9-6705-2009, 2009.

Whitaker, R. J., Grogan, D. W., and Taylor, J. W.: Geographic Barriers Isolate Endemic Pop-ulations of Hyperthermophilic Archaea, Science, 301, 976-978, doi:10.1126/science.1086909, 2003.

Whitfield, J.: Biogeography: Is Everything Everywhere?, Science, 310, 960-961, doi:10.1126/science.310.5750.960, 2005.

Womack, A. M., Bohannan, B. J. M., and Green, J. L.: Biodiversity and biogeography of the atmosphere, Philosophical Transactions of the Royal Society B: Biological Sciences, 365, 3645-3653, doi:10.1098/rstb.2010.0283, 2010. 